\title{
THE EFFECT OF GIVING DETERGENTS TO THE GROWTH OF Azolla microphylla IN BRACKISH WATER
}

\author{
Annisa Presti Parbo ${ }^{1 *}$, Irwan Effendi ${ }^{2}$, Syahril Nedi ${ }^{2}$ \\ ${ }^{1}$ Student of The Faculty of Fisheries And Marine Science University of Riau, Pekanbaru \\ ${ }^{2}$ Lecturer at the Faculty of Fisheries And Marine Science University Riau, Pekanbaru \\ annisaparbo17@gmail.com
}

\begin{abstract}
This research conducted on March to April 2019 with the aim of knowing the effect of detergent on the growth of A. microphylla. The results showed wet weight growth ranging from 2-23.81 grams (control) and 1.43-8.35 grams (addition of detergent). Absolute weight growth ranges from 3.63-8.47 grams and 1.77-3.28 grams. Growth in the number of colonies between 39.66-295 colonies and 37.66-98.33 colonies. Growth doubling time day 3-23 and 3.63-7.66 days. The growth of wet weight and the number of colonies of A. microphyla increased in each data collection on the control treatment media, while the addition of detergent treatment increased on the day 5 and day 10 and on the day 15 and day 20 decreased.
\end{abstract}

Keywords : Detergent, Brackish Water, Azolla microphylla

\section{PENDAHULUAN}

Azolla merupakan genus dari tanaman paku air yang mengapung. Ada 7 spesies dari genus ini yaitu A. caroliniana, A. filiculoides, A. mexicana, $A$. microphylla, A. rubra, A. nilotica, dan A. pinnata. A. microphylla sebagai tumbuhan paku air dan salah satu pakan alami yang melimpah ketersediaannya di alam yang belum termanfaatkan secara optimal. Dibanding spesies lainnya, A. microphylla lebih toleran terhadap temperatur tinggi, sehingga sangat baik bila dibudidayakan pada kondisi iklim tropis seperti di Indonesia.

A. microphylla sebagai tumbuhan air yang memiliki potensi dalam menurunkan kadar pencemar air limbah yang memilki kadar organik tinggi pada berbagai penelitian mengenai fitoremediasi. Penelitian oleh Muhtadin (2012) menggunakan A. microphylla sebagai remediator limbah cair laundry selama 2 minggu dengan konsentrasi limbah di bawah $100 \%$.

Pencemaran air menjadi masalah yang perlu mendapat perhatian seksama karena air sudah banyak tercemar oleh bermacam-macam limbah dari hasil kegiatan manusia, baik dari kegiatan rumah tangga, industri dan kegiatan lainnya (Wardhana, 2004). Perairan payau merupakan ekosistem pesisir semi tertutup, sebagai daerah peralihan antara air tawar yang berasal dari sungai dengan air asin dari laut. Wilayah perairan payau bersifat sangat subur dan produktif dikarenakan kandungan nutrien yang tinggi dari laut dan sungai. Kegiatan manusia di sekitar perairan payau akan mempengaruhi dinamika ekosistem perairan payau. Salah satu penyebab terjadinya pencemaran air adalah limbah deterjen yang sisa buangan bahan kimianya lebih tahan dan tidak berubah dalam berbagai media. Limbah deterjen tersebut merendahkan tegangan permukaan maupun tegangan dalam air itu 
sendiri dan akibat-akibat ini masih memberikan beraneka ragam efek samping terhadap lingkungan oleh kandungan zat kimia deterjen.

Deterjen Soklin Smart termasuk merek deterjen yang bisa didapatkan di minimarket sampai supermarket. Deterjen ini memiliki bahan aktif $26 \%$ (sebagai Sodium Alkylbenzenesulfonate) termasuk bahan aktif yang tinggi daripada deterjen merek lain. A. microphylla yang berfungsi sebagai fitoremediasi, yang diduga ada pengaruhnya pada media tercemar. Untuk itu penulis merasa perlu dilakukan penelitian tentang pengaruh pemberian deterjen terhadap pertumbuhan $A$. microphylla pada air payau.

\section{METODOLOGI PENELITIAN}

Penelitian ini telah dilaksanakan pada bulan Maret - April 2019. Penelitian ini dilakukan di Laboratorium Mikrobiologi Laut, Jurusan Ilmu Kelautan, Fakultas Perikanan dan Kelautan, Universitas Riau.

Metode yang digunakan pada penelitian ini ialah metode eksperimen, menggunakan Rancangan Acak Lengkap (RAL) dengan variabel penambahan deterjen dengan 5 perlakuan dan 3 ulangan.

$\mathrm{a}:$ tanpa deterjen (kontrol) $\quad\left(\mathrm{a}_{0}\right)$

$\mathrm{b}$ : penambahan deterjen $0,1 \mathrm{mg} / \mathrm{l} \quad\left(\mathrm{a}_{1}\right)$

$c$ : penambahan deterjen $0,2 \mathrm{mg} / \mathrm{l} \quad\left(\mathrm{a}_{2}\right)$

$\mathrm{d}$ : penambahan deterjen $0,3 \mathrm{mg} / \mathrm{l} \quad\left(\mathrm{a}_{3}\right)$

e : penambahan deterjen $0,4 \mathrm{mg} / \mathrm{l} \quad\left(\mathrm{a}_{4}\right)$

Peneliti mengamati secara makroskopis untuk melihat pertumbuhan berat, pertumbuhan bobot mutlak, pertumbuhan koloni, dan growth doubling time tumbuhan A. microphylla.

Penelitian ini dilakukan dengan

penyajian wadah sebagai berikut :

Pupuk Kandang 500 g + Volume Air 11

liter dengan salinitas $3 \mathrm{ppt}$

Bibit A. microphylla diletakkan pada masing-masing media yang telah didiamkan selama 3 hari sebanyak 2 gram dengan kondisi sampel yang seragam. Sampel A. microphyla berasal dari Marine Science Biotecnology Club (MSBC) yang telah diperbanyak sebelumnya. Selanjutnya dilakukan pengukuran kualitas air sebagai data pendukung untuk mengetahui kondisi air (media tumbuh), pengukuran dilakukan pada hari ke-0 $\left(b_{0}\right)$, hari ke-5 $\left(b_{1}\right)$, hari ke$10\left(b_{2}\right)$, hari ke-15 $\left(b_{3}\right)$, dan hari ke-20 $\left(b_{4}\right)$.dengan mengukur parameter air yaitu pH dan suhu. Pertumbuhan A. microphylla diamati dengan cara mengukur pertumbuhan berat basah dan pertumbuhan jumlah koloni dari tumbuhan $A$. microphylla serta menghitung pertumbuhan bobot mutlak dan doubling time untuk melihat perbedaan tumbuhan $A$ microphylla yang berada pada media perlakuan deterjen yang berbeda.

Analisis data yang dilakukan secara kuantitatif pertumbuhan tanaman berguna untuk memberikan gambaran pertumbuhan tanaman secara kuantitatif dan faktor-faktor yang mendukung proses tersebut dapat diketahui dengan jelas. Pengukuran dan pengamatan dilakukan dengan menggunakan rumus sebagai berikut:

\section{Pertumbuhan Bobot Mutlak}

Pertumbuhan biomassa mutlak adalah selisih antara berat pada akhir penelitian dengan berat pada awal penelitian (Effendie, 2002):

Keterangan :

$$
\mathrm{W}=\mathrm{Wt}-\mathrm{Wo}
$$

$\mathrm{W}=$ Pertumbuhan mutlak (gram)

$\mathrm{Wt}=$ Bobot biomassa pada akhir (gram)

Wo = Bobot biomassa pada awal (gram)

\section{Growth Doubling Time}

Waktu penggandaan (doubling time) adalah waktu yang dibutuhkan oleh $A$. microphylla untuk bertambah secara teratur menjadi dua kali lipat dari semula (Mitchell, 1974). 


$$
\begin{aligned}
& \frac{\text { In Nti }- \text { In Nto }}{\text { ti }- \text { to }} \\
& \text { GRi }=\text { Ti }=\frac{\text { In } 2}{\text { GRi }}
\end{aligned}
$$

Keterangan :

$\mathrm{GRi}=$ Growth rate atau laju pertumbuhan A. microphylla (hari)

Nto = Luas cover area tanaman pada waktu t(o)

$\mathrm{Nti}=$ Luas cover area tanaman pada waktu t(i)

ti-to = Selang atau selisih waktu pengukuran awal dan akhir (hari)

$\mathrm{Ti}=$ Doubling time atau waktu penggandaan (hari)

Data pertumbuhan tumbuhan $A$. microphylla dari perlakuan penambahan deterjen yang berbeda dan dilakukan pengamatan selama periode hari ke- 0,5 , 10, 15, dan 20, diuji dengam Analysis of
Variance (ANOVA) dan tingkat kepercayaan $(a=0,05)$.

\section{HASIL DAN PEMBAHASAN}

\section{Parameter Kualitas Air}

Hasil pengukuran parameter air diperoleh suhu berkisar $24,8-28{ }^{\circ} \mathrm{C}$ dan $\mathrm{pH}$ berkisar 5,8-6,5. Suhu tertinggi terdapat pada media perlakuan $a_{0}$ pada hari ke- 0 yaitu $28{ }^{\circ} \mathrm{C}$, sedangkan yang terendah terdapat pada media perlakuan $\mathrm{a}_{1}$ dan $\mathrm{a}_{4}$ hari ke- 10 yaitu $24,8{ }^{\circ} \mathrm{C}$. Pengukuran $\mathrm{pH}$ tertinggi terdapat pada media perlakuan $\mathrm{a}_{1}$ dan $\mathrm{a}_{4}$ hari ke- 0 yaitu 6,5 , sedangkan yang terendah terdapat pada media perlakuan $\mathrm{a}_{4}$ hari ke- 5 yaitu 5,8. Dari penelitian yang telah dilakukan terlihat bahwa kualitas air dalam kondisi normal. Hal ini sesuai dengan pernyataan Lumpkin dan Plucknett dalam Mentari et al. (2016) bahwa suhu optimal bagi pertumbuhan Azolla sp. berada pada rentang $18-28{ }^{\circ} \mathrm{C}$.

Tabel 1. Hasil Pengukuran Kualitas Air

\begin{tabular}{cllllll}
\hline \multicolumn{2}{c}{ Perlakuan } & $\mathrm{b}_{0}$ & $\mathrm{~b}_{1}$ & $\mathrm{~b}_{2}$ & $\mathrm{~b}_{3}$ & $\mathrm{~b}_{4}$ \\
\hline Suhu $\left({ }^{\circ} \mathrm{C}\right)$ & & & & & & \\
& $\mathrm{a}_{0}$ & 28 & 25,1 & 25,3 & 26 & 25,8 \\
& $\mathrm{a}_{1}$ & 27,6 & 25,3 & 24,8 & 25,5 & 25,6 \\
& $\mathrm{a}_{2}$ & 27,6 & 25 & 25,1 & 25,8 & 25,6 \\
& $\mathrm{a}_{3}$ & 27,6 & 25,3 & 25,3 & 25,1 & 25,1 \\
& $\mathrm{a}_{4}$ & 27,6 & 25 & 24,8 & 25,3 & 25,3 \\
\hline $\mathrm{pH}$ & & & & & & \\
& $\mathrm{a}_{0}$ & 6,3 & 6,3 & 6,3 & 6,3 & 6,4 \\
& $\mathrm{a}_{1}$ & 6,5 & 6,3 & 6,3 & 6,4 & 6,4 \\
& $\mathrm{a}_{2}$ & 6,3 & 6,1 & 6,3 & 6,3 & 6,4 \\
& $\mathrm{a}_{3}$ & 6,4 & 6,1 & 6,3 & 6,3 & 6,3 \\
& $\mathrm{a}_{4}$ & 6,5 & 5,8 & 6,2 & 6,4 & 6,1 \\
\hline
\end{tabular}

Keterangan : a : perlakuan penambahan deterjen $\mathrm{b}$ : hari pengambilan data

\section{Pertumbuhan Berat Basah}

Pertumbuhan berat basah $A$. microphyla pada perlakuan kontrol berkisar antara 2-23,81 gram, pada perlakuan $\mathrm{a}_{1}$ berkisar antara 2-8,35 gram, pada perlakuan $a_{2}$ berkisar antara 2-7,89 gram, pada perlakuan $a_{3}$ berkisar antara 2-6,87 gram, dan pada perlakuan $\mathrm{a}_{4}$ berkisar antara 1,43-6,40 gram. 


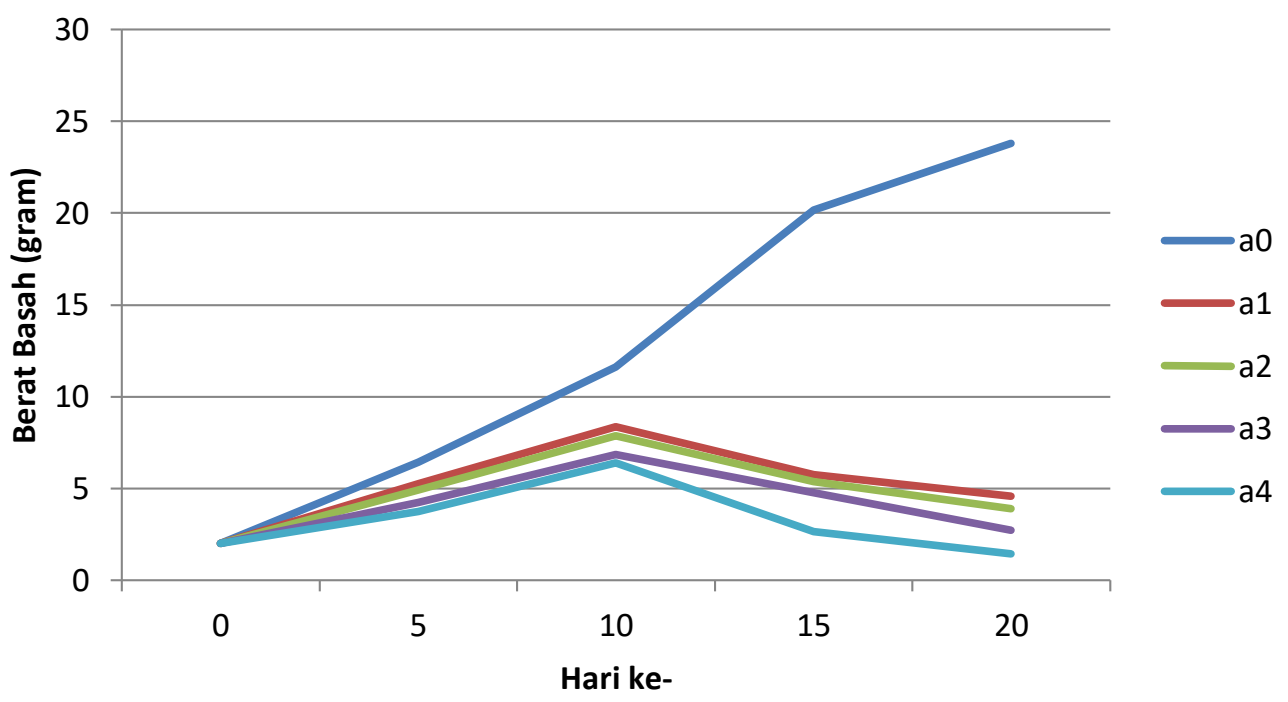

Gambar 1. Pertumbuhan Berat Basah A. microphylla

Hasil penelitian menunjukkan pertumbuhan berat basah A. microphyla mengalami kenaikan disetiap pengambilan data pada media perlakuan kontrol, sedangkan pada perlakuan $\mathrm{a}_{1}, \mathrm{a}_{2}, \mathrm{a}_{3}$, dan $\mathrm{a}_{4}$ mengalami kenaikan pada pengambilan data hari ke- 5 dan hari ke- 10 dan pada pengambilan data hari ke- 15 dan hari ke20 mengalami penurunan disebabkan $A$. microphyla mengalami kematian

Pertumbuhan berat basah tertinggi terdapat pada perlakuan kontrol pengambilan data hari ke- 20 yaitu 23,81 gram dan terendah pada perlakuan $\mathrm{a}_{4}$ pengambilan data hari ke- 20 yatitu 1,43 gram. Untuk lebih jelas dapat dilihat pada Gambar 2. Hasil uji statistik pada perlakuan $\mathrm{a}_{0}$ (kontrol) berbeda sangat nyata dengan perlakuan $\mathrm{a}_{1}(0,1$ gram deterjen $), \mathrm{a}_{2}(0,2$ gram deterjen), $a_{3}(0,3$ gram deterjen), dan $\mathrm{a}_{4}(0,4$ gram deterjen).

Pada perlakuan penambahan deterjen selama penelitian mengalami peningkatan dari awal perlakuan namun berangsur menurun pada pengambilan data

hari ke- 15. Menurut Djojosiwoto (2000), biomassa Azolla sp. dapat bertambah dua kali lipat dalam waktu kurang dari tujuh hari. Berdasarkan Salafiyah (2014) keefektifan lama tanam Azolla sp. terhadap nilai deterjen diketahui mampu menyerap ion-ion hasil perombakan deterjen karena komponen penyusun deterjen terdiri atas bahan organik. Asam-asam organik dan $\mathrm{CO}_{2}$ yang dihasilkan dari proses penguraian bahan organik tersebut selanjutnya dapat diabsorbsi oleh tumbuhan air melalui akar setelah berbentuk ion, misalnya ion asetat dan ion karbonat. Itu artinya, penyerapan ion-ion hasil penguraian deterjen yang semangkin lama akan menyebabkan penurunan nilai deterjen pada air limbah.

Semakin lama waktu penyerapan, maka semakin besar pula polutan yang diserap oleh tumbuhan air. Namun faktor ini berlaku apabila tumbuhan air telah mencapai titik jenuh sehingga berapapun waktu kontak berikutnya, tumbuhan air tidak akan mampu menyerap polutan lagi dan hal ini dapat menjadi pedoman untuk menentukan kapan tumbuhan tersebut harus di-recovery (Sudiro, 2013).

\section{Pertumbuhan Bobot Mutlak}

Pertumbuhan bobot mutlak pada perlakuan kontrol berkisar antara 3,63-8,57 gram, pada perlakuan $a_{1}$ berkisar antara (- 
2,60)-3,28 gram, pada perlakuan $\mathrm{a}_{2}$ berkisar antara (-2,50)-2,98 gram, pada perlakuan $a_{3}$ berkisar antara (-2,08)-2,63 gram, dan pada perlakuan $\mathrm{a}_{4}$ berkisar antara $(-3,73)$ 2,63 gram.

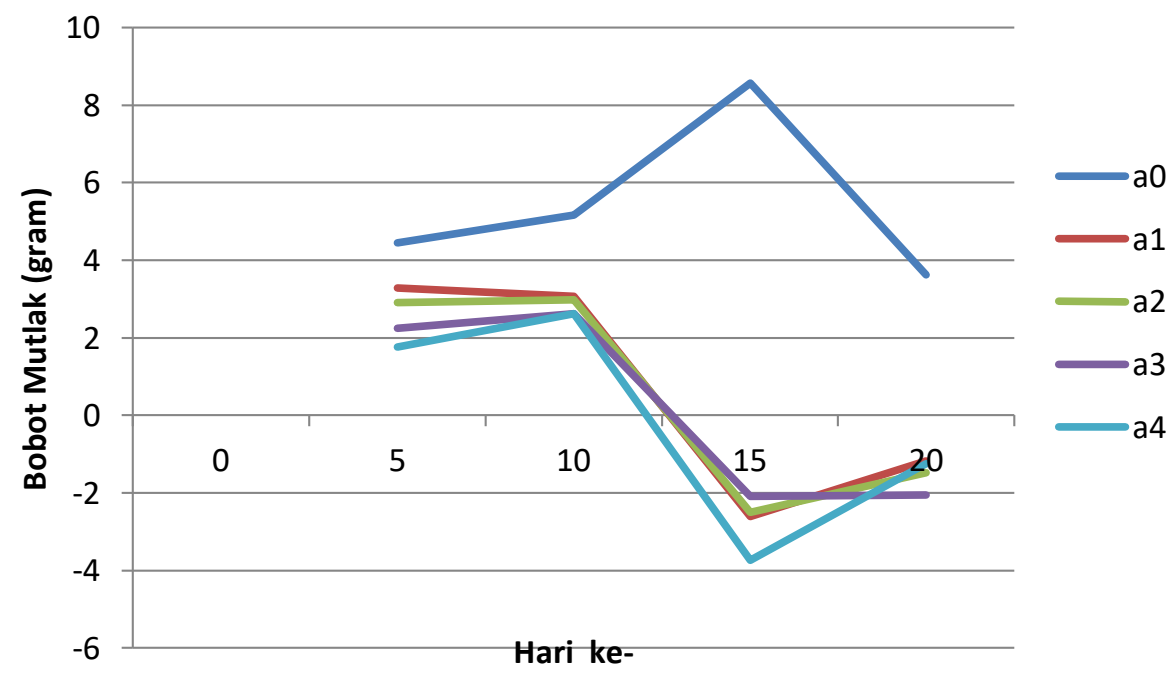

Gambar 2. Pertumbuhan Bobot Mutlak A. microphylla

Pertumbuhan bobot mutlak $A$. microphyla tertinggi pada perlakuan kontrol pengambilan data hari ke- 15 yaitu 8,57 gram, sedangkan yang terendah pada perlakuan $a_{4}$ pengambilan data hari ke- 5 yaitu $(-3,73)$ gram. Untuk lebih jelas dapat dilihat pada Gambar 2. Hasil uji statistik pada perlakuan $\mathrm{a}_{0}$ (kontrol) berbeda nyata dengan perlakuan $\mathrm{a}_{1}$ ( 0,1 gram deterjen) dan $\mathrm{a}_{2}$ (0,2 gram deterjen) dan berbeda sangat nyata dengan perlakuan $a_{3}(0,3$ gram deterjen $)$ dan $\mathrm{a}_{4}(0,4$ gram deterjen). Pertumbuhan bobot mutlak A. microphyla pada media perlakuan tidak terjadi sebanyak kontrol disebabkan A. microphyla menyerap deterjen, berdasarkan penelitian yang dilakukan oleh Ahmady et al. (2014) perkembangan $A$. microphylla pada media perlakuan tidak sebanyak kontrol.

\section{Pertumbuhan Jumlah Koloni}

Pertumbuhan jumlah koloni pada media kontrol berkisar antara 39,66-295 koloni, pada media $a_{1}$ berkisar antara 39,33-118 koloni, pada media $a_{2}$ berkisar antara 38-103 koloni, pada media $\mathrm{a}_{3}$ berkisar antara 35,33-98,33 koloni, dan pada media $\mathrm{a}_{4}$ berkisar antara 38-93,33 koloni.

Pertumbuhan jumlah koloni $A$. microphyla pada media perlakuan kontrol mengalami pertambahan jumlah koloni dari hari ke- 5 sampai hari ke- 20. Pada media perlakuan $\mathrm{a}_{1}, \mathrm{a}_{2}, \mathrm{a}_{3}$, dan $\mathrm{a}_{4}$ mengalami pertambahan jumlah koloni pada pengambilan data hari ke- 5 dan hari ke 10, sedangkan pada hari ke- 15 mulai mengalami penurunan jumlah koloni hingga hari ke- 20. Pertumbuhan jumlah koloni tertinggi pada perlakuan kontrol pengambilan data hari ke- 20 yaitu 295 koloni dan terendah pada perlakuan $\mathrm{a}_{4}$ pengambilan data hari ke- 20 yaitu 22,33 koloni. Untuk lebih jelas dapat dilihat pada Gambar 3. Hasil uji statistik pada perlakuan $a_{0}$ (kontrol) berbeda nyata dengan perlakuan $a_{1}(0,1$ gram deterjen) dan berbeda sangat nyata dengan perlakuan $\mathrm{a}_{2}$ $(0,2$ gram deterjen $), a_{3}(0,3$ gram deterjen $)$ dan $\mathrm{a}_{4}(0,4$ gram deterjen $)$. 


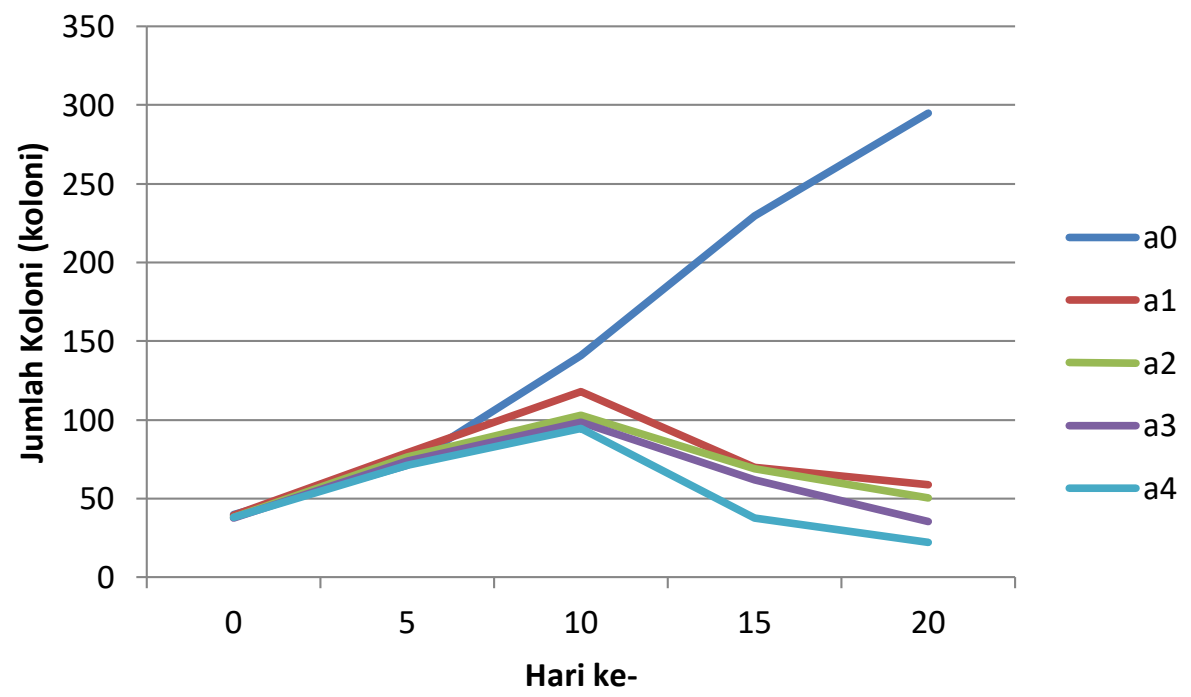

Gambar 3. Pertumbuhan Jumlah Koloni A. microphylla

Berdasarkan hasil pengamatan pertumbuhan jumlah koloni A. microphylla tiap 5 hari, didapat angka laju pertumbuhan pertumbuhan dari tiap perlakuan. Laju pertumbuhan jumlah koloni A. microphylla tertinggi terdapat pada perlakuan $\mathrm{a}_{0}$ (kontrol) yaitu berkisar antara 39,66- 295 koloni. Hal ini dikarenakan kondisi media A. microphylla tidak tercemar deterjen, sedangkan pada perlakuan $\mathrm{a}_{1}, \mathrm{a}_{2}, \mathrm{a}_{3}$, dan $\mathrm{a}_{4}$ meskipun kondisi media tercemar deterjen dan penambahan deterjen melebihi baku mutu limbah cair menurut Pergub Jatim No. 72 Tahun 2013 yaitu sebesar 10 mg/l untuk deterjen, dosis deterjen tersebut tidak sampai membuat pertumbuhan terhambat.

\section{Growth Doubling Time}

Waktu penggandaan perlakuan kontrol tercepat pada pengambilan data hari ke- 5 yaitu 3 hari dan terlama pada pengambilan data hari ke- 20 yaitu 23 hari.
Waktu penggandaan perlakuan $\mathrm{a}_{1}, \mathrm{a}_{2}, \mathrm{a}_{3}$, dan $\mathrm{a}_{4}$ terlama pada pengambilan data hari ke10 yaitu 7,60 hari $\left(a_{1}\right), 7,66$ hari $\left(a_{2}\right.$ dan $\left.a_{3}\right)$, dan 6,9 hari $\left(\mathrm{a}_{4}\right)$.

Growth doubling time perlakuan $\mathrm{a}_{1}$, $\mathrm{a}_{2}, \mathrm{a}_{3}$, dan $\mathrm{a}_{4}$ mulai mengalami penurunan pada pengambilan data hari ke- 15 karena berat basah juga mengalami kematian. Menurut Djojosuwito (2000), Azolla sp. dapat berkembang biak secara vegetatife. Perbanyakan vegetative, cabang-cabang sisi memisahkan diri dari cabang utama atau batang induk, diikuti oleh pembentukan lapisan penutup luka akibat pemisahan. Cabang-cabang sisi yang memisah tumbuh menjadi tumbuhan dewasa yang bias membentuk cabang-cabang baru. Perbanyakan vegetative ini sangat cepat dengan waktu ganda biomassa sekitar 4-5 hari. Tumbuhan yang memisahkan diri ini sampai menjadi Azolla sp. memerlukan waktu 10-15 hari. Untuk lebih jelas dapat dilihat pada Gambar 4. 


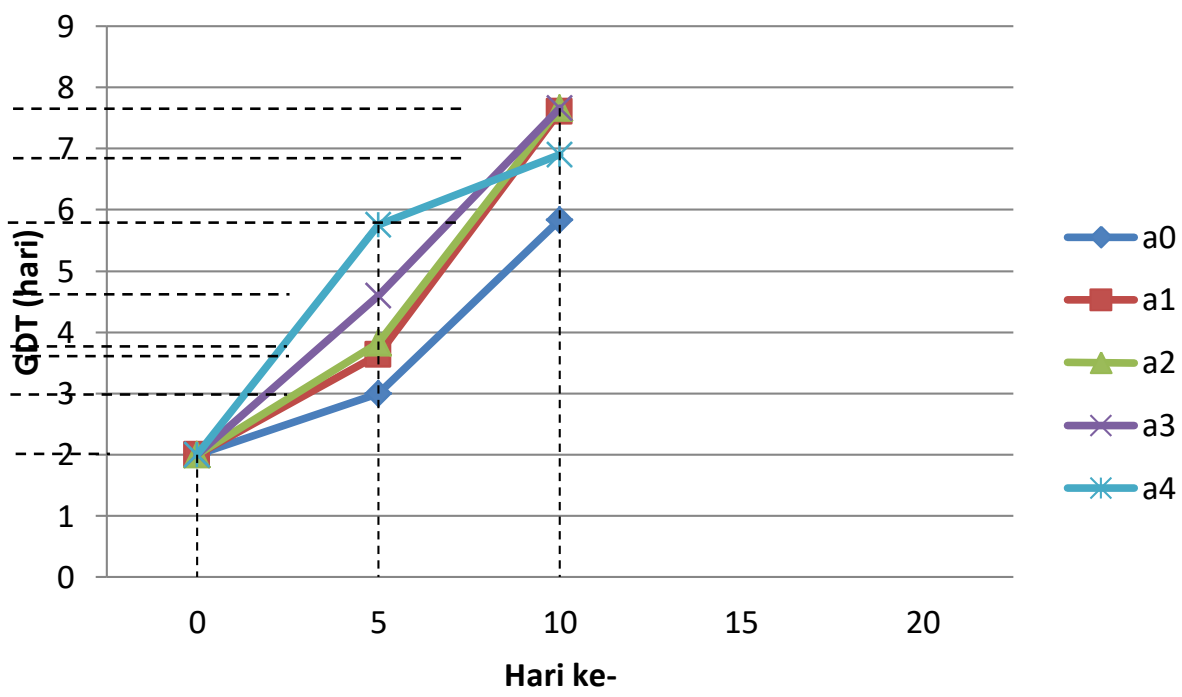

Gambar 4. Growth Doubling Time A. microphylla

\section{KESIMPULAN}

Berdasarkan hasil penelitian dapat disimpulkan bahwa pemberian deterjen dapat mempengaruhi pertumbuhan (berat basah, bobot mutlak, jumlah koloni, dan growth doubling time). Semangkin besar dosis deterjen yang diberikan ke media tanam, pertumbuhan A. microphyla semakin menurun. Pertumbuhan berat basah dan jumlah koloni A. microphyla mengalami kenaikan disetiap pengambilan data pada media perlakuan kontrol, sedangkan pada perlakuan penambahan deterjen mengalami kenaikan pada hari ke5 dan hari ke- 10 dan pada hari ke- 15 dan hari ke-20 mengalami penurunan.

\section{SARAN}

Perlu dilakukan penelitian lebih lanjut mengenai berapa persen kadar bahan pencemar dari deterjen dalam wadah percobaan yang berhasil diserap oleh tumbuhan A. microphyla.

\section{DAFTAR PUSTAKA}

1. Ahmady, G.A., P. Patana, R. Ezraneti, (2014). Azolla microphylla sebagai Biokonsentrasi Pencemaran Timbal $(\mathrm{Pb})$. Program Studi Manajemen Sumberdaya Perairan, Fakultas Pertanian, Universitas Sumatera Utara.

2. Djojosuwito, S., (2000). Azolla Pertanian Organik dan Multiguna. Penerbit Kanisius. Yogyakarta.

3. Effendie, M.I., (2002). Biologi Perikanan (P. 113) Yayasan Pustaka Nusantara. Yogjakarta.

4. Mentari, A., N. Probosunu, dan R.I. Adharini, (2016). Pemanfaatan Azolla sp. untuk Menurunkan Kandungan COD (Chemical Oxygen Demand) dalam Limbah Laundry. Jurnal Perikanan Universitas Gadjah Mada Volume 18(2) pages 67-72.

5. Mitchell, D.S., (1974). The Development of Excessive Populations of Aquatic Plants. in Mitchell, D.S. (Editor). Aquatic Vegetation and it is Use and Control. UNESCO. Paris.

6. Muhtadin, (2012). Pengaruh Penambahan Azolla microphylla terhadap Penurunan Kadar COD dan Fosfat pada Variasi Konsentrasi Limbah Cair Laundry "Bg" di Kelurahan 
Warungboto Kecamatan Umbulharjo Yogyakarta. [Skripsi]. Yogyakarta : Universitas Ahmad Dahlan.

7. Pergub Jatim [Peraturan Gubernur Jawa Timur], (2013). Baku Mutu Limbah Cair.

8. Salafiyah, N., (2014). Pengaruh Laa Tanam dan Luas Penutupan Azolla microphylla Terhadap Kualitas Kimia dan Fisika Limbah Cair Laundry. Jurusan Biologi Fakultas Sains dan Teknologi. Univeritas Negeri Maulana Malik Ibrahim Malang.

9. Sudiro, (2013). Kajian Efektifitas Tanaman Air Lemna minor dan Hydrilla verticillata dalam Mereduksi BOD dan COD sebagai Upaya Perbaikan Kualitas Limbah Cair Industri Tahu. Jurnal Spectra. Volume 9 Pages 21.

10. Wardhana, W.A., (2004). Dampak Pencemaran Lingkungan (Edisi Revisi). Yogyakarta : Andi Offset. 